\title{
THE KENNEWICK SKELETON: CHRONOLOGICAL AND BIOMOLECULAR CONTEXTS
}

\author{
R E Taylor ${ }^{1}$ David Glenn Smith ${ }^{2}$ John R Southon ${ }^{3}$ \\ ABSTRACT. A human skeleton recovered near Kennewick, Washington, USA in 1996 has been dated to the early Holocene \\ on the basis of multiple radiocarbon determinations, an analysis of a style of a temporally diagnostic projectile point found \\ embedded in the ilium of the skeleton, and geological investigations of the locality where the skeleton was recovered. Based \\ on morphological criteria, the Kennewick skeleton, which is one of the most complete early Holocene human skeletons recov- \\ ered so far in the Western Hemisphere, appears to be more similar to those of modern South Asians and Europeans than to \\ modern Native Americans or to contemporary indigenous populations of Northeast Asia.
}

\section{INTRODUCTION}

In late July 1996, a human skull was accidently discovered in shallow water adjacent to an embankment on the southern shore of a lake (Lake Wallula) created by a flood control and hydroelectric dam on the Columbia River at Columbia Park within the community of Kennewick, State of Washington, USA $\left(46^{\circ} 13^{\prime} \mathrm{N}, 19^{\circ} 10^{\prime} \mathrm{W}\right)$. Over several months following the initial discovery of the skull, post-cranial skeletal parts were periodically collected at the site primarily by Dr James C Chatters, a local private archaeological consultant (Chatters 2000; Nickens 1998; McManamon 1999a).

Based primarily on various conventional morphological criteria along with the presence of historic artifacts, the skeleton, which has come to be referred to as "Kennewick Man" from the "Columbia Park site", was initially thought to be that of a historic-contact period Euro-American settler. However, during the cleaning of the bone, Dr Chatters noted the presence of an object embedded in the right ilium of the pelvis. CAT-scans were interpreted as suggesting that the object appeared to be similar to a "Cascade Point," a diagnostic projectile point associated with the early to middle Holocene Cascade Phase—one of the prehistoric archaeological complexes defined for southwestern Washington. A radiocarbon determination obtained in August 1996 on a total amino-acid fraction of a metacarpal bone yielded a ${ }^{14} \mathrm{C}$ value (UCR-3476/CAMS-29578) of $8410 \pm 60 \mathrm{BP}$ (Taylor et al. 1998).

The presence of an early Holocene human skeleton in North America exhibiting skeletal morphological features determined by several physical anthropologists with long experience evaluating North American aboriginal skeletal materials as uncharacteristic of recent Native American populations engendered both widespread popular media and scientific interest. The term "Caucasoid" was associated with the remains and so reported in the popular press. It had been initially used to characterize "gross morphology, not presumed origin" (Chatters 2000: 316). Unfortunately, such usage did not explain to the general reader the problematical historical contexts, semantic difficulties, and inappropriate connotations sometimes associated with the use of this term.

This paper will review issues primarily involving the overall contextual interpretation of the ${ }^{14} \mathrm{C}$ data obtained on different bones from the Kennewick skeleton including problems of estimating the magnitude of reservoir corrections in light of the skeleton's $\delta^{13} \mathrm{C}$ values and the reported wide range of protein preservation exhibited in different bones of what is assumed to be a single skeleton.

\footnotetext{
${ }^{1}$ Radiocarbon Laboratory, Department of Anthropology, Institute of Geophysics and Planetary Physics, University of California, Riverside, USA. Email: retaylor@ citrus.ucr.edu.

${ }^{2}$ Department of Anthropology, University of California, Davis, California, USA

${ }^{3}$ Center for Accelerator Mass Spectrometry, University of California, Lawrence Livermore National Laboratory, Livermore, California, USA
}

(C) 2001 by the Arizona Board of Regents on behalf of the University of Arizona Radiocarbon, Vol 43, Nr 2B, 2001, p 965-976

Proceedings of the 17 th International ${ }^{14} \mathrm{C}$ Conference, edited by I Carmi and E Boaretto 


\section{THE KENNEWICK SKELETON}

The human bone materials now generally designated as the Kennewick skeleton [CENWW.97.Kennewick] from the Columbia Park Site were recovered in a disarticulated condition, distributed over an area of at least $30 \mathrm{~m}^{2}$, about $3 \mathrm{~m}$ offshore and in about $45 \mathrm{~cm}$ of water. It has been assumed the sediments containing the remains had collapsed into the near shore water at a single point and then scattered by subsequent water action (Nickens 1998).

Based on a overall evaluation of skeletal morphometric data collected on the Kennewick skeleton, it was determined first by Chatters and subsequently confirmed by Powell and Rose (1999) that the Kennewick remains represent a single male individual, approximately $175 \mathrm{~cm}\left(5^{\prime} 9^{\prime \prime}\right)$ in stature, who had experienced a number of injuries throughout his life, and died between 45 and 50 years of age. A number of years before his death, he had broken two right ribs and had suffered a fracture of the right humerus. Perhaps at the same time, a projectile point was embedded within the right iliac blade of the pelvis. Most of the teeth show extreme wear with only trace amounts of enamel remaining on the incisors, canines, and premolars. Given the considerable attrition of the dentition, dental traits were difficult to characterize. From a taphonomic perspective, the Kennewick remains represent an individual who was most probably intentionally buried rather than left to decompose on the surface. In terms of the number of bone elements recovered, the Kennewick skeleton represents one of the most complete early Holocene human skeletons currently known from the Western Hemisphere.

Based on measurements of the skull, it was reported that the most similar samples appeared to be those from the south Pacific and Polynesia as well as the Ainu of Japan, a pattern identified from other studies of early Holocene American crania from North and South America (Steele and Powell 1992, 1994; Jantz and Owsley 1997). On the basis of an overall initial morphological evaluation, it was concluded that the Kennewick skeleton can be excluded, on the basis of its cranial morphology, from late Holocene American Native American groups (Powell and Rose 1999).

\section{CHRONOLOGICAL CONTEXTS}

\section{Geologic and Geomorphological Analyses}

Extensive geologic and geomorphological studies have been undertaken at the Columbia Park site in an effort to determine the age of the sediments from which the skeleton was assumed to be derived (Wakeley et al. 1998; Huckleberry and Stein 1999). Specific issues addressed include whether the geologic evidence supported the age of the skeleton determined by the initial ${ }^{14} \mathrm{C}$ age obtained on the bone from the Kennewick skeleton. Also, since the Kennewick Skeleton was found disarticulated in a secondary context, geologic studies were also designed to determine, if possible, the original location of the buried skeleton within the stratigraphic profile prior to its disturbance.

The sediments from which the Kennewick Man remains were derived, were analyzed as being composed of relatively fine-textured alluvium capped by an eolian/alluvial deposit, both modified by soil formation. A series of 12 embankment soil profiles ( $\mathrm{CPP}=$ Columbia Park Profile) exposed by erosion and 6 cores $(\mathrm{CPC}=$ Columbia Park Core $)$ collected from lower sediments at the water's edge over a 300-m section of river front have been examined to provide a more detailed reconstruction of the geologic context. Figure 1 presents the results of the geomorphological studies of these sections and cores along with a listing of $\operatorname{six}{ }^{14} \mathrm{C}$ determinations obtained on freshwater shell and sediment humates (Huckleberry and Stein 1999: Figure 1). 


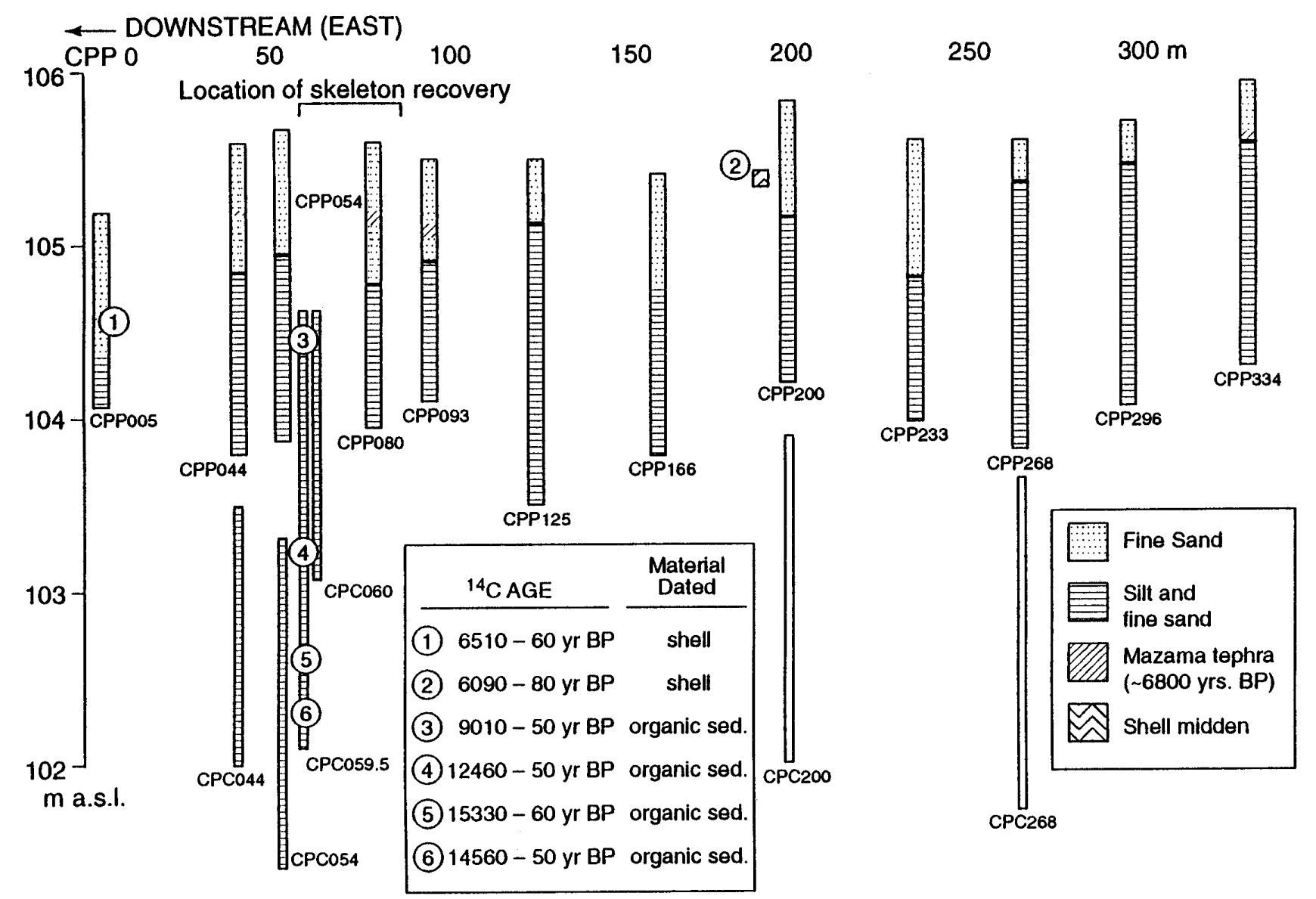

Figure 1 Fence diagram of stratigraphy at the Columbia Park site, Kennewick, Washington, in relationship to ${ }^{14} \mathrm{C}$ determinations of freshwater shell and humates and the occurrence of Mt Masama tephra. Radiocarbon determinations (from Wakeley et al. 1998): (1) $6510 \pm 60$ BP: Beta-11383 [shell]; (2) 6090 \pm 80: Beta-113977 [shell], (3) $9010 \pm 50$ BP: WW-1626 [sediment organics], (4) 12,460 \pm 50 BP: WW-1738 [sediment organics]. Adapted from Huckleberry and Stein (1999:Figure 1). 
Figure 2 provides details on 1) three cores collected near the location where the Kennewick skeletal materials were recovered, 2) four ${ }^{14} \mathrm{C}$ values of materials from one of these cores (CPC059.5), and 3) two interpretations of the results of the geomorpholgical analysis (Huckleberry and Stein 1999: Figure 2). Both Figures 1 and 2 present the location of Mt Mazama tephra in the soil sections.

Initial studies of the soil profiles (Wakeley et al. 1998) divided the sedimentary structure into five units (Unit I-V) while a follow-up analysis (Huckeberry et al. 1998) characterized only two major lithostratigraphic units by grouping sedimentary Units I-III in a Lithostratigraphic Unit I and Units IV-V into a Lithostratigraphic Unit II. The later interpretation will be used in this discussion.

Lithostratigraphic Unit I is characterized as containing predominantly very fine to fine sand with no internal bedding or textural grading. Its lower portions contain discontinuous volcanic tephra, which was identified as deriving from Mt Mazama and thus dating to about 6800 BP. The underlying Lithostratigraphic Unit II was characterized as buried stratified well-sorted fine sand formed by a series of overbank flood deposits mixed and modified by subsequent bioturbation and pedogenesis. A series of soil humates extracted from coring in this unit exhibited ${ }^{14} \mathrm{C}$ values ranging in age from about 9000 to $15,000 \mathrm{BP}$. The youngest of the soil humate ${ }^{14} \mathrm{C}$ values $(9010 \pm 50 \mathrm{BP}$ [WW-1626/ CAMS-44572]) is derived from the base of a concretion-bearing sediment within the upper zone of Lithostratigraphic Unit II which, on the basis of the comparison of organic and carbonate concentrations in the sediment and adhering to the Kennewick bones (see next paragraph), was inferred to be that which originally contained the Kennewick skeleton. Unfortunately, the exact nature of the organics comprising the soil humates used to obtain the ${ }^{14} \mathrm{C}$ value was not specified. The investigators concluded that "if we assume that the Mazama tephra is in situ and that the ${ }^{14} \mathrm{C}$ age [of the soil humate sample] is correct, then the geologically correlated age for the skeleton is 6700-9000 BP" (Huckleberry and Stein 1999:22).

Sediments removed from the skeleton by Huckleberry and Stein (1999) were examined by a series of conventional optical and instrumental techniques including granulometry, thin-section (micromorphology), thermogravimetric, X-ray diffraction, and trace element analysis. In large part, the purpose of these studies was to match sediments from the skeleton and from the assumed discovery location at the Columbia Park site through a combination of physical and chemical tests. Special attention was focused on calcitic concretions, which were discontinuously distributed over the surface of the bones giving them a "lumpy oatmeal" appearance. This was due to the determination that the soil profile at the discovery site contained concretion-bearing sediment, which under visual inspection appeared to be very similar to that adhering to portions of the Kennewick skeleton. It was determined that the organic and carbonate contents of the concretions extracted from the skeleton and from sediment samples recovered from the upper part of the sequence designated as Lithostratigraphic Unit II were almost identical. The conclusion was that "the concretion on the skeleton was formed when the human remains were within the upper part of Lithostratigraphic Unit II" (Huckleberry and Stein 1999:17).

\section{Embedded Lithic Artifact}

An initial examination of the skeleton by CAT-scan revealed the presence of a lithic artifact embedded in a portion of the ilium. Initial X-ray radiographs were made but the impregnation of all bone by fine gained silt and mineral deposits resulted in the bone being almost as radiodense as the stone point. Subsequent digitized CAT-scans undertaken as part of a later osteological assessment were used to differentiate the bone, remove it from the digital image, and produce a three-dimensional model of the embedded point (Powell and Rose 1999; Chatters 2000). 


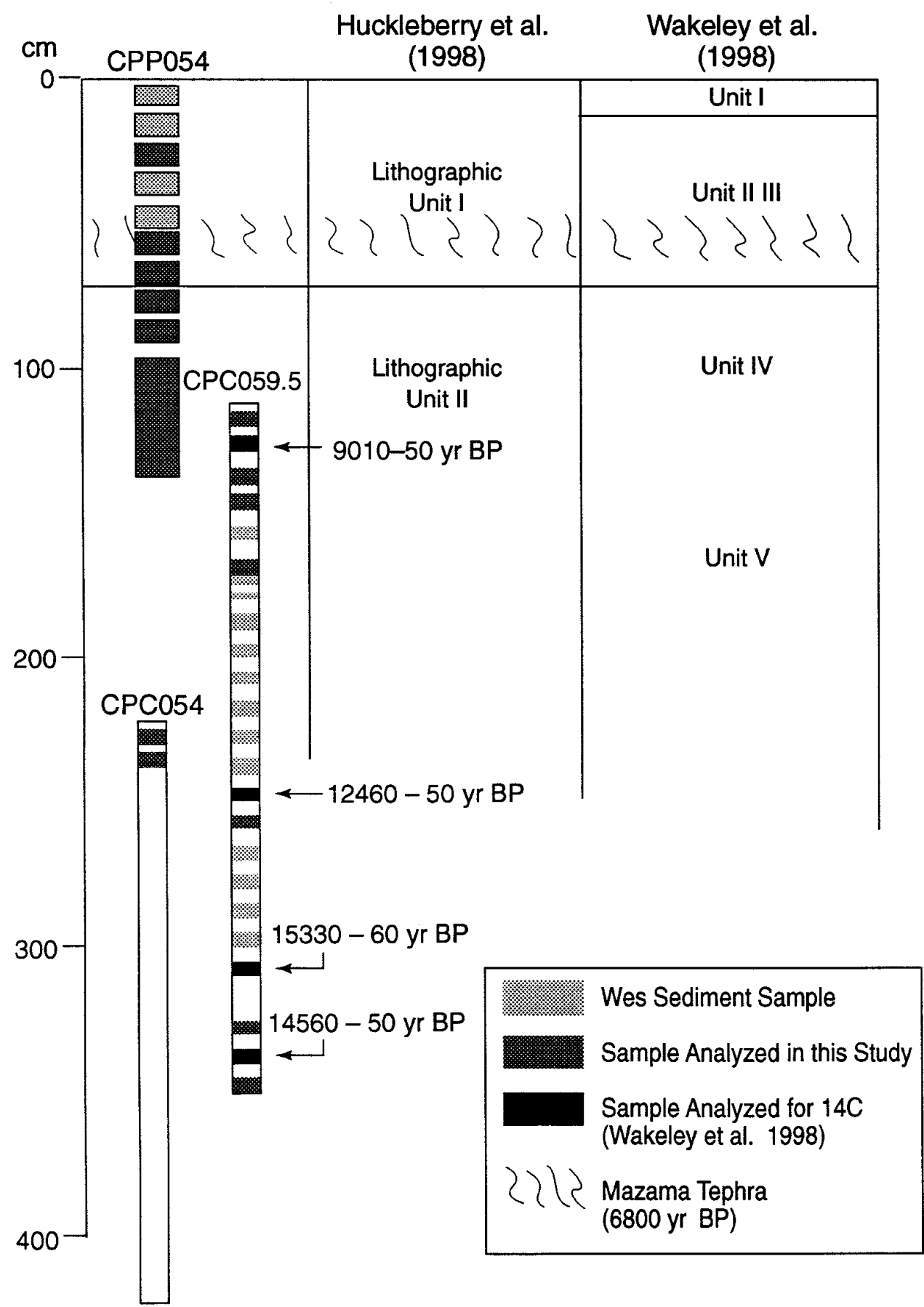

Figure 2 Provenience of ${ }^{14} \mathrm{C}$ samples at CPP054 and CPC059.5 in terms of the stratigraphic nomenclature of Huckleberry et al. (1998) and Wakeley et al. (1998). Adapted from Huckleberry and Stein (1999:Figure 2). 
A visual examination determined that the raw material used in the manufacture of the artifact was a dark gray, medium-grained basalt or andesite. CAT scans revealed that the artifact was bifacially worked and lanceolate (leaf-shaped) in overall shape. A typological assessment suggested that the artifact resembled a Cascade Point, a dart point type first characterized by Butler (1961:28-29) who considered it a diagnostic trait of the Cascade Phase, the second earliest of five phases originally defined for the Lower Snake River culture sequence of southwestern Washington (Leonhardy and Rice 1970).

Cascade phase assemblages are present in sites throughout the Pacific Northwest (Newman 1966; Nelson 1969; Rice 1972). They have often been associated with volcanic ash deposits of the Mt Mazama eruption, which critical reviews of the large corpus of ${ }^{14} \mathrm{C}$ values place within a century of 6800 BP (Hallet et al. 1997:Table 1; Bacon 1983; Zdanowicz et al. 1999:623). However, there is some uncertainty about the temporal placement of different lithic variants associated with the Cascade phase in terms of whether they immediately pre- or post-date the Mt Mazama eruption. Lanceolate (leaf-shaped) points with serrated edges were common in the pre-Mazaman assemblages from the Columbia Plateau. However, Fagan (1999:5) concluded that the Columbia Park specimen embedded in the Kennewick skeleton more closely resembles points most often immediately postdating the Mt Mazama ash. On this basis, in his view, the specimen is thought to represent "a tool made and used during Early Archaic times between 5,000 and 7,000 years ago." Chatters (2000: 298) identified serrated edges on the sample and, on this basis, suggested that it should predate the Mazama ashfall and thus date to between 5000 and 8000 BP.

\section{Radiocarbon Analysis}

Table 1 lists ${ }^{14} \mathrm{C}$ determinations obtained directly on various bone fragments of the Kennewick Skeleton. A single ${ }^{14} \mathrm{C}$ analysis was obtained in 1996 on a fragment of a left metacarpal bone whereas four analyses were obtained in 1999 on two other bone fragments-a right metacarpal and portions of a left tibial crest - which had been split into two portions and sent to three ${ }^{14} \mathrm{C}$ laboratories. One laboratory (UCR) analyzed both of the bones analyzed in 1999 while the Beta Analytic laboratory analyzed a split of the metacarpal and the University of Arizona NSF Accelerator Facility analyzed a split of the tibial crest. All samples were measured for their ${ }^{14} \mathrm{C}$ content by accelerator mass spectrometry (AMS). In the two cases-at the UCR and Beta Analytic laboratories-following chemical pretreatment and production of graphitic carbon, AMS ${ }^{14} \mathrm{C}$ measurements were obtained at the Center for Accelerator Mass Spectrometry at the University of California Lawrence Livermore National Laboratory.

There is an extensive and detailed literature on problems in the ${ }^{14} \mathrm{C}$ dating of sub fossil bone extending back for several decades (e.g. Taylor 1987:53-61 with earlier literature cited; Stafford et al. 1988; Hedges and Law 1989; Taylor 1994; Hedges and Van Klinken 1992). All of these studies highlight the significant variability in the degree to which endogenous carbon-containing fractions in bone are retained and are, or are not, protected from contamination by a wide variety of physical and chemical diagenetic mechanisms. It is well known that obtaining accurate ${ }^{14} \mathrm{C}$ age estimates on bone requires attention to detail in sample preparation and an appreciation that each bone may present an unique chemical challenge if the isolation of a fraction that contains only autochthonous carbon atoms is to be consistently achieved.

An important factor in obtaining accurate individual bone ${ }^{14} \mathrm{C}$ values is the degree to which a bone sample has retained significant amounts its principal protein component, collagen. To measure the degree to which collagen is retained in the bone sample, the UCR laboratory obtains a profile of the constituent amino acids of a total hydrolysate of the bone by ion-exchange chromatography follow- 
ing extensive physical cleaning under magnification of the bone surface followed by sonication in dilute $\mathrm{HCl}$. In the UCR laboratory, routine bone ${ }^{14} \mathrm{C}$ analyses are undertaken on samples which exhibit a collagen-like amino acid composition and retain in excess of 5\% of the amino acid carbon content (AACC) of a modern bone standard. This criterion was applied to the initial human bone analyzed by the UCR laboratory in 1996.

This sample (UCR-3476/CAMS-29578) exhibited a collagen-like amino acid profile and contained significant amounts of amino acid carbon (Table 1). However, all laboratories that analyzed the two Kennewick bones submitted in 1999, including UCR, reported that the residual organic carbon content was very much reduced from the 1996 bone sample. For example, although UCR-3807/CAMS60684 contained about $14.3 \%$ AACC, the amino-acid profile was non-collagen-like while UCR3806/CAMS-60683 exhibited a non-collagen-like amino acid profile and contained only $2.3 \%$ AACC. We interpret the anomalous $\delta^{13} \mathrm{C}$ values for both of the UCR 1999 bone samples as reflecting a combined diagenetic and dietary signal. As a consequence, both UCR $1999{ }^{14} \mathrm{C}$ analysis have been expressed as fraction modern with the equivalent ${ }^{14} \mathrm{C}$-concentration inferred age value reported as an "apparent ${ }^{14} \mathrm{C}$ age." Although the Beta Analytical Laboratory reported a collagen yield of $0.3 \%$, the ${ }^{14} \mathrm{C}$ value reported (BETA-133993) was essentially identical to the 1996 value reported by the UCR laboratory. By contrast, both the University of Arizona ${ }^{14} \mathrm{C}(\mathrm{AA}-34818)$ and ${ }^{13} \mathrm{C}$ values obtained on a sample with a carbon yield of $0.05 \%$ were significantly anomalous.

Table 1 Radiocarbon analyses of Kennewick human bone

\begin{tabular}{|c|c|c|c|c|c|c|}
\hline \multirow[b]{2}{*}{ Lab nr } & \multirow[b]{2}{*}{ Sample designation } & \multirow{2}{*}{$\begin{array}{l}\text { Bone } \\
\text { preservation }^{\mathrm{a}}\end{array}$} & \multirow{2}{*}{$\begin{array}{l}\text { Fraction } \\
\text { measured }\end{array}$} & \multirow{2}{*}{$\begin{array}{l}\delta^{13} \mathrm{C} \\
(\% o)\end{array}$} & \multicolumn{2}{|c|}{ Radiocarbon analysis } \\
\hline & & & & & $\mathrm{F}_{\mathrm{m}} \mathrm{b}$ & ${ }^{14} \mathrm{C}$ age (BP) \\
\hline \multicolumn{7}{|l|}{ a. 1996 Analysis } \\
\hline $\begin{array}{l}\text { UCR-3476/ } \\
\text { CAMS-29578 }\end{array}$ & $\begin{array}{l}\text { 5th left metacarpal } \\
\text { APS-CPS-01 }\end{array}$ & $68.8 \%(\mathrm{C})$ & $\begin{array}{l}\text { Total amino } \\
\text { acids }\end{array}$ & -14.9 & - & $8410 \pm 60$ \\
\hline \multicolumn{7}{|l|}{ b. 1999 Analyses } \\
\hline BETA-133993d & $\begin{array}{l}\text { 1st right metacarpal } \\
\text { CENWW.97.R.24(Mta) }\end{array}$ & $\underline{\mathrm{e}}^{\mathrm{e}}$ & $\begin{array}{l}\text { Base treated, } \\
\mathrm{HCl} \text { insoluble }\end{array}$ & -12.6 & - & $8410 \pm 40$ \\
\hline $\begin{array}{l}\text { UCR-3807/ } \\
\text { CAMS-60684 }\end{array}$ & $\begin{array}{l}\text { 1st right metacarpal } \\
\text { CENWW.97.R.24/Mta) }\end{array}$ & $14.3 \%(\mathrm{NC})$ & $\begin{array}{l}\text { Total amino } \\
\text { acids }\end{array}$ & -10.8 & $0.3633 \pm 0.0014$ & $(8130 \pm 40)^{f}$ \\
\hline $\begin{array}{l}\text { UCR-3806/ } \\
\text { CAMS-60683 }\end{array}$ & $\begin{array}{l}\text { Left tibial crest } \\
\text { CENWW.97.R.24/Mta) }\end{array}$ & $2.3 \%(\mathrm{NC})$ & $\begin{array}{l}\text { Total amino } \\
\text { acids }\end{array}$ & -10.3 & $0.4216 \pm 0.0015$ & $(6940 \pm 30)^{f}$ \\
\hline AA-34818g & $\begin{array}{l}\text { Left tibial crest, } \\
\text { CENWW.97.L.20b }\end{array}$ & ${ }^{\mathrm{h}}$ & Gelatin & -21.9 & - & $5750 \pm 100$ \\
\hline
\end{tabular}

${ }^{a}$ UCR characterization of bone preservation expressed as \% of amino acid carbon content (AACC) of modern bone standard. $\mathrm{C}=$ collagen-like amino acid composition. $\mathrm{NC}=$ non-collagen amino acid composition.

${ }^{\mathrm{b}} \mathrm{F}_{\mathrm{m}}=$ fraction modern where $1.0=$ "modern". $\mathrm{pM}($ percent modern $)=\mathrm{F}_{\mathrm{m}} \times 100$.

'Taylor et al. (1998)

dReported by D Hood in McManamon (1999b)

eD Hood (Beta Analytic) reports that the "amount of collagen extracted" was $0.3 \%$ as a percent concentration, a value very low due to the "high mineral content of the submitted bone."

${ }^{\mathrm{f}}$ Reported as "apparent ${ }^{14} \mathrm{C}$ age."

geported by D Donahue in McManamon (1999b)

${ }^{\mathrm{h}} \mathrm{D}$ Donahue (University of Arizona) reports that the "carbon yield for this sample was $0.05 \% \ldots$ well below the yield for which we would usually quote a result." 


\section{Estimate of Reservoir Effect}

In undertaking the $1996{ }^{14} \mathrm{C}$ analysis, the $\delta^{13} \mathrm{C}$ value exhibited by UCR-3476/CAMS-29578 suggested the presence of a marine reservoir signal presumably reflecting a high percentage intake of marine derived biomass, i.e. salmon, in the diet of Kennewick Man. Salmon was assumed as the dominant fish in the diet based on contact period ethnographic accounts and archaeological data although steelhead (Oncorhynchus spp.) has also been suggested (Chatters 2000:299). In reporting the initial result (Taylor et al. 1998), it was assumed that $100 \%$ marine and terrestrial diets would give rise in a total amino acid fraction to $\delta^{13} \mathrm{C}$ values of -12.8 and $-19.6 \%$, respectively, following the approach outlined in Chisholm et al. (1982). Given the $\delta^{13} \mathrm{C}$ value of $-14.9 \%$ for UCR-3476/ CAMS-29578, a marine dietary protein contribution of $70 \pm 10 \%$ was calculated assuming an uncertainly of $\pm 1 \%$ in the dietary end points.

Assuming that early Holocene Columbia River salmon accumulated most of their biomass within the Gulf of Alaska in a manner similar to that observed today (Groot and Margolis 1991), we can calculated a marine offset correction for the Kennewick sample. ${ }^{14} \mathrm{C}$ ages for early 20th century marine shell from the Gulf of Alaska average $860 \mathrm{BP}$ (Robinson and Thompson 1981) while terrestrial ages were close to 110 years (Stuiver et al. 1986, 1998). On this basis, the marine reservoir correction for this region was 750 years.

Table 2 Radiocarbon-dated Early Holocene human skeletal samples from western North America older than Kennewick skeleton

\begin{tabular}{|c|c|c|}
\hline Site & Sample/fraction & ${ }^{14} \mathrm{C}$ age (BP), lab nr \\
\hline Anzick, Montana ${ }^{\mathrm{a}}$ & $\begin{array}{l}\text { Glycine } \\
\text { Glutamic acid } \\
\text { Hydroxyproline } \\
\text { Gelatin (untreated) } \\
\text { Alanine } \\
\text { Aspartic acid }\end{array}$ & $\begin{array}{l}10,940 \pm 90(\mathrm{AA}-2981) \\
10,820 \pm 100(\mathrm{AA}-2979) \\
10,710 \pm 100(\mathrm{AA}-2980) \\
10,500 \pm 400(\mathrm{AA}-313 \mathrm{~B}) \\
10,370 \pm 130(\mathrm{AA}-2982) \\
10,240 \pm 120(\mathrm{AA}-2978)\end{array}$ \\
\hline Buhl, Idaho ${ }^{\mathrm{b}}$ & $\begin{array}{l}\text { Total acid insoluble } \\
\text { organics }\end{array}$ & $10,675 \pm 95$ (BETA-43055/ETH-7729) \\
\hline Angeles Mesa, California ${ }^{c}$ & $\begin{array}{l}\text { Total acid insoluble } \\
\text { organics }\end{array}$ & $10,500 \pm 2000($ UCLA-1924) \\
\hline Mostin, California & $\begin{array}{l}\text { Total acid insoluble } \\
\text { organics }\end{array}$ & $\begin{array}{l}10,470 \pm 490\left(^{(U C L A-2171}\right)^{\mathrm{d}} \\
10,260 \pm 340\left(^{\mathrm{UCLA}}-1795 \mathrm{~A}\right)^{\mathrm{c}}\end{array}$ \\
\hline $\begin{array}{l}\text { Arlington Springs, } \\
\text { Santa Rosa Island, California }\end{array}$ & $\begin{array}{l}\text { Total acid insoluble } \\
\text { XAD-treated gelatin }\end{array}$ & $\begin{array}{l}10,080 \pm 810\left(\text { UCLA-1899) }{ }^{\mathrm{c}}\right. \\
10,960 \pm 80(\text { CAMS-16810) }\end{array}$ \\
\hline $\begin{array}{l}\text { On-Your-Knees-Cave, } \\
\text { Prince of Wales Island, Alaska }\end{array}$ & XAD-treated gelatin & $9730 \pm 60(\mathrm{CAMS}-29873)$ \\
\hline Gordon Creek, Colorado ${ }^{f}$ & $\begin{array}{l}\text { Total acid insoluble } \\
\text { organics }\end{array}$ & $9700 \pm 250(\mathrm{GX}-0530)$ \\
\hline Spirit Cave, Nevada ${ }^{\mathrm{g}}$ & Total amino acids & $9430 \pm 60(\mathrm{UCR}-3260 / \mathrm{CAMS}-12352)$ \\
\hline $\begin{array}{l}\text { Wizard Beach, Pyramid Lake, } \\
\text { Nevada }\end{array}$ & $\begin{array}{l}\text { Total acid insoluble } \\
\text { organics } \\
\text { Total amino acids }\end{array}$ & $\begin{array}{l}9515 \pm 155(\mathrm{GX}-19422) \\
9110 \pm 60(\mathrm{UCR}-3445 \mathrm{~A} / \mathrm{CAMS}-26369) \\
9210 \pm 60(\mathrm{UCR}-3445 \mathrm{~B} / \mathrm{CAMS}-26370) \\
9250 \pm 60(\mathrm{UCR}-3445 \mathrm{C} / \mathrm{CAMS}-28124)\end{array}$ \\
\hline La Brea, Los Angeles, California ${ }^{\mathrm{h}}$ & Total amino acids & $9000 \pm 80($ UCLA-1292B $)$ \\
\hline
\end{tabular}

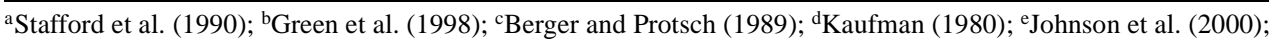

fBreternitz et al. (1971); ' Kirner et al. (1997); hBerger et al. (1971). 
The spread in marine shell ages from around the Gulf (Robinson and Thompson 1981; unpublished data) and results from archived pre-1950 salmon scales (Brown et al. 1988; T Brown, personal communication) suggest that a reasonable estimate for the geographic variability in this correction is the equivalent of \pm 60 years. The scatter in paired wood-shell ${ }^{14} \mathrm{C}$ ages from the British Columbia coast (Southon et al. 1990; unpublished data) indicates that early Holocene variations of this correction of up to \pm 150 years cannot be excluded. Adding these in quadrature, we calculate \pm 160 years as a conservative estimate of the overall uncertainty for the reservoir correction at 7000-8000 BP in the Gulf of Alaska.

Based on these results and the estimated marine dietary contribution, we calculate the corresponding marine reservoir offset for the Kennewick ${ }^{14} \mathrm{C}$ values as $530 \pm 140$. On the basis of these considerations, we have calculated a reservoir-corrected ${ }^{14} \mathrm{C}$ age of $7880 \pm 150 \mathrm{BP}$ for UCR-3476/CAMS29578.

The Kennewick skeleton is one of ten directly ${ }^{14} \mathrm{C}$ dated early Holocene human skeletons from western North America currently known to be older than 7500 BP (Table 2 on previous page). However, unlike Kennewick, where almost $90 \%$ of the bones have been recovered, all but two of the other skeletons are represented by very fragmentary remains. The Kennewick skeleton represents the most intensively studied North American prehistoric human skeleton not only from the perspective of its geological and chronological provenience but also its morphological status. Studies have also been recently initiated to examine its genetic affiliation with respect to modern New World Native American populations.

Table 3 Native American- and Asian-specific mtDNA haplogroups: diagnostic control region (CR) and restriction fragment length polymorphism (RFLP) mutations

\begin{tabular}{|c|c|c|c|}
\hline \multirow[b]{2}{*}{ Haplogroup } & \multirow[b]{2}{*}{ CR mutations } & \multicolumn{2}{|c|}{ RFLP mutations } \\
\hline & & Restriction enzyme & Site \\
\hline \multicolumn{4}{|c|}{ A. Native American-specific haplogroups } \\
\hline A & 16290T, 16319A & + Hae III & 663 \\
\hline $\mathrm{B}$ & $16217 \mathrm{C}$ & \multicolumn{2}{|c|}{ [9 bp deletion in Region V] } \\
\hline $\mathrm{C}$ & $16298 \mathrm{C}, 16327 \mathrm{~T}$ & $\begin{array}{l}\text {-Hind II } \\
+ \text { Alu I }\end{array}$ & $\begin{array}{l}13259 \\
13262\end{array}$ \\
\hline $\mathrm{D}$ & $16325 \mathrm{C}, 16362 \mathrm{C}$ & -Alu I & 5176 \\
\hline$X$ & $16278 \mathrm{~T}$ & $\begin{array}{l}\text {-Dde I } \\
+ \text { Acc I }\end{array}$ & $\begin{array}{l}1715 \\
14465\end{array}$ \\
\hline \multicolumn{4}{|c|}{ B. Asian-specific haplogroups } \\
\hline $\mathrm{F}$ & $16278 \mathrm{~T}, 16311 \mathrm{C}$ & & \\
\hline G & $16017 \mathrm{C}, 16129 \mathrm{~A}, 16223 \mathrm{~T}$ & $\begin{array}{l}+ \text { Hae II } \\
+ \text { Hha I }\end{array}$ & $\begin{array}{l}4830 \\
4831\end{array}$ \\
\hline $\mathrm{Y}$ & $16231 \mathrm{C}, 16266 \mathrm{~T}$ & $\begin{array}{l}\text { +Mbo I } \\
\text {-Hae III }\end{array}$ & $\begin{array}{l}7933 \\
8391\end{array}$ \\
\hline $\mathrm{Z}$ & 16224C, 16260T, 16298C & +Dde I & 11074 \\
\hline
\end{tabular}




\section{BIOMOLECULAR CONTEXTS}

Studies of mutational variations in mitrochondrial DNA (mtDNA) in human cells have been employed to determine genetic relationships between and among contemporary and ancient populations (Schurr 2000). Studies carried out over the last decade on modern Native American populations have established that all members can be grouped within one of five matrilines or mtDNA haplogroups (see Table 3 on previous page). Great interest was expressed in assigning the Kennewick skeleton to one of these matrilines or determining that it belonged to some non-North American matriline.

The laboratory of one of us (DGS) has undertaken mtDNA studies on samples of Kennewick bone. Regretfully, mitrochondrial DNA (mtDNA) restriction and sequencing analyses of DNA extracted from the Kennewick skeleton have not been successful to date in identifying its mtDNA haplogroup since modern DNA from a known researcher who studied these skeletal remains co extracted during their analysis. Because a known positive control sample of mtDNA readily amplified when mixed with the Kennewick sample, the failure of the latter to amplify resulted from an absence of DNA rather than from inhibitors co-extracted from the sample. Other laboratories examining the Kennewick bone have reported similar negative results.

\section{SUMMARY}

Geological, archaeological, and ${ }^{14} \mathrm{C}$ data are consistent in assigning an early Holocene age to the Kennewick skeleton, one of the most complete human skeletons of that age so far reported from a New World site. From a morphological perspective, the Kennewick specimen appears to be more similar to those of modern South Asians and Europeans than to modern Native Americans or to contemporary indigenous populations of Northeast Asia. Regretfully, attempts to extract mtDNA from the Kennewick skeleton to assign it to a known mtDNA matriline have, to date, been unsuccessful.

\section{ACKNOWLEDGMENTS}

The UCR Radiocarbon Laboratory is supported in part by the National Science Foundation, the Western Center Community Foundation, the Gabrielle O Vierra Memorial Fund, the Academic Senate Intermural Research Fund and the College of Humanities, Arts and Social Sciences, University of California, Riverside. The laboratory of DGS is supported by the National Science Foundation. Portions of this research were performed under the auspices of the US DOE, under contract W-7405Eng-48. The dedicated laboratory work of Donna Kirner, Karen Selsor, Debra George (UCR) and Ripan Malhi (UCD) is acknowledged and very much appreciated. This is contribution 00/07 of the Institute of Geophysics and Planetary Physics, University of California, Riverside.

\section{REFERENCES}

Bacon CR. 1983. Eruptive history of Mount Mazama and Crater Lake Caldera, Cascade Range, U.S.A. Journal of Volcanology and Geothermal Research 18:57-115.

Berger R, Protsch RR. 1989. UCLA radiocarbon dates XI. Radiocarbon 31(1):55-67.

Berger R, Protsch RR, Reynolds R, Rozaire C, Sackett JR. 1971. New radiocarbon dates based on bone collagen of California paleoindians. Contributions of the University of California Archaeological Research Facility 12:43-9.

Breternitz DA, Swedlund AC, Anderson D. 1971. An early burial from Gordon Creek, Colorado. American
Antiquity 36:170-82.

Brown TA, Quay PD, Francis RC, Holmgren D. 1998. Radiocarbon as tracer and chronometer: advances and applications of radiocarbon to climate and carbon cycle studies [Abstract]. EOS 79:5167.

Butler BP. 1961. The Old Cordilleran Culture in the Pacific Northwest. Occasional Papers of the Idaho State College Museum 5. Pocatello, Idaho.

Chatters JC. 2000. The recovery and first analysis of an Early Holocene human skeleton from Kennewick, Washington. American Antiquity 65:291-316.

Chisholm BS, Nelson DE, Schwarcz HP. 1982. Stable- 
carbon isotope ratios as a measure of marine versus terrestrial protein in ancient diets. Science 216:11312.

Fagan JL. 1999. Analysis of lithic artifact embedded in the Columbia Park Remains. Archeology \& Ethnography Program, National Park Service, United States Department of Interior. http://www.cr.nps.gov/aad/ kennewick/fagan.htm.

Green TJ, Cochran B, Fenton TW, Woods JC, Titmus GL, Tieszen L, Davis MA, Miller SJ. 1998. The Buhl burial: a paleoindian woman from Southern Idaho. American Antiquity 63:457-67.

Groot C, Margolis L, editors. 1991. Pacific salmon life histories. Vancouver: UBC Press.

Hallet DJ, Hills LV, Clague JJ. 1997. New accelerator mass spectrometry radiocarbon ages for the Mazama tephra layer from Kootenay National Park, British Columbia, Canada. Canadian Journal of Earth Sciences 34:1202-9.

Hedges REM, Law IA. 1989. The radiocarbon dating of bone. Applied Geochemistry 4:249-53.

Hedges REM, Van Klinken GJ. 1992. A review of current approaches in the pretreatment of bone for radiocarbon dating by AMS. Radiocarbon 34(3):279-91.

Huckleberry G, Stafford TW, Chatters JC. 1998. Preliminary geoarchaeological studies at Columbia Park, Kennewick, Washington, USA. Report submitted to the U.S. Army Corps of Engineers, Walla Walla District, 23 March 1998.

Huckleberry G, Stein JK. 1999. Analysis of sediments associated with human remains found at Columbia Park, Kennewick, WA. Archeology \& Ethnography Program, National Park Service, United States Department of Interior. http://www.cr.nps.gov/aad/kennewick/huck_stein.htm.

Jantz RL, Owsley DW. 1997. Pathology, taphonomy and cranial morphometrics of the Spirit Cave Mummy. Nevada Historical Society Quarterly 40:57-61.

Johnson JR, Stafford TW, Ajie HO, Morris DP. 2000. Arlington Springs revisited. Abstracts, Society for California Archaeology, Riverside, California.

Kaufman T. 1980. Early prehistory of the Clear Lake areas, Lake County, California [PhD dissertation]. University of California, Los Angeles.

Kirner DL, Burky R, Taylor RE, Southon JR. 1997. Radiocarbon dating organic residues at the microgram level. Nuclear Instruments and Methods and Physics Research B123:214-7.

Leonhardy FC, Rice DG. 1970. A proposed culture typology for the Lower Snake River Region, Southwestern Washington. Northwest Anthropology Research Notes 4(1):1-29.

McManamon FP. 1999a. The initial scientific examination, description, and analysis of the Kennewick Man human remains. Archeology \& Ethnography Program, National Park Service, United States Department of Interior. http://www.cr.nps.gov/aad/kennewick/mc- manamon.htm.

McManamon FP. 1999b. Determination that the Kennewick Human Skeletal Remains are "Native American" for the Purposes of the Native American Graves Protection and Repatriation Act (NAGPRA). Archeology \& Ethnography Program, National Park Service, United States Department of Interior. http:// www.cr.nps.gov/aad/kennewick/c14memo.htm.

Nelson CM. 1969. The Sunset Creek Site (45-KT-28) and its place in Plateau Prehistory. Report of Investigations, No. 47. Pullman, Washington: Washington State University Laboratory of Anthropology.

Newman TM. 1966. Cascadia Cave. Occasional papers of the Idaho State Museum 18. Pocatello, Idaho.

Nickens PR. 1998. Discovery and recovery of human remains from the Columbia Park Site, Kennewick, WA, July-September 1996. Report prepared for the U.S. Department of Justice, Environmental and Natural Resources Division, Washington, D.C.

Powell JF, Rose JC. 1999. Report on the Osteological Assessment of the "Kennewick Man" skeleton (CENWW.97.Kennewick). Archeology \& Ethnography Program, National Park Service, United States Department of Interior. http://www.cr.nps.gov/aad/ kennewick/Powell_rose.htm.

Rice DG. 1972. The Windust phase in lower Snake River region prehistory. Report of Investigations, No. 50. Pullman, Washington: Washington State University Laboratory of Anthropology.

Robinson SW, Thompson G. 1981. Radiocarbon corrections for marine shell dates with application to southern Pacific Northwest Coast prehistory. Syesis 14:4557.

Schurr TG. 2000. Mitochondrial DNA and the pepling of the New World. American Scientist 88:246-53.

Southon JR, Nelson DE, Vogel JS. 1990. A record of past ocean-atmosphere radiocarbon differences from the Northeast Pacific. Paleoceanography 5:197-206.

Stafford TW, Brendel K, Duhamel RC. 1988. Radiocarbon, ${ }^{13} \mathrm{C}$ and ${ }^{15} \mathrm{~N}$ analysis of fossil bone: Removal of humates with XAD-2 resin. Geochimica et Cosmochimica Acta 52:2197-206.

Stafford TJ, Hare PE, Currie L, Jull AJT, Donahue D. 1990. Accuracy of North American human skeleton age. Quaternary Research 34:111-20.

Steele DG, Powell JF. 1992. The peopling of the America: the paleobiological evidence. Human Biology 63: 301-36.

Steele DG, Powell JF. 1994 Paleobiological evidence of the peopling of the America: a morphometric view. In: Bonnischsen R, Steele DG, editors. Method and theory for investigating the peopling of the Americas. Corvallis: Center for the Study of the First Americans. p 141-63.

Stuiver M, Pearson GW, Braziunas T. 1986. Radiocarbon age calibration of marine samples back to $9000 \mathrm{cal} \mathrm{yr}$ BP. Radiocarbon 28(2B):980-1021. 
Stuiver M, Reimer PJ, Braziunas TF. 1998. High-precision radiocarbon age calibration for terrestrial and marine samples. Radiocarbon 40(3):1127-52.

Taylor RE. 1987. Radiocarbon dating: an archaeological perspective. Orlando: Academic Press.

Taylor RE. 1994. Radiocarbon dating of bone using accelerator mass spectrometry: current discussions and future directions. In: Bonnichsen R, Gentry Steele D, editors. Method and theory for investigating the peopling of the Americas. Corvallas: Oregon State University, Center for the Study of the First Americans. p 27-44.

Taylor RE, Kirner DL, Southon JR, Chatters JC. 1998.
Radiocarbon dates of Kennewick Man. Science 280: 1171-2.

Wakeley LD, Murphy WL, Dunbar JB, Warne, AG, Briuer FL, Nickens PR. 1998. Geologic, geoarchaeologic, and historical investigation of the discovery site of ancient remains in Columbia Park, Kennewick, Washington. Technical Report GL-98-13, Vicksburg (Mississippi): U.S. Army Engineer Waterways Experiment Station.

Zdanowicz CM, Zielinski GA, Germani MS. 1999. Mount Mazama eruption: calendrical age verified and atmospheric impact assessed. Geology 27:621-4. 